\title{
Supporting Aquaculture in Ghana with Hydrographic Data
}

\author{
Perry Addison ${ }^{1}$, John Kwamena Amos ${ }^{2}$ \\ ${ }^{1,2}$ Civil Engineering Department Takoradi Polytechnic
}

\begin{abstract}
Hydrography has been around since the 13th century. Although it was intended to mainly support vessels to navigate safely, the increase shift of attention from nautical charts to marine resources, especially to the hydrocarbon industry, expanded the use of hydrographic data. Currently, countries with hydrographic capabilities are able to use hydrographic information to support different maritime and related activities. This research shows how hydrographic data can be used to support Aquaculture in Ghana, specifically looking at inland aquaculture on Lake Volta where bulk of Ghana's aquaculture production comes from. Through the use of relevant data mainly secondary sourced, on how Canada is employing hydrography to solve similar challenges in the area under consideration, and relevant literature, solutions were proffered to tackle the challenges in Ghana. It was apparent that, by integrating hydrography into aquaculture, fish farmers will be able to manage their farms more efficiently to boost production.
\end{abstract}

Keywords: Hydrography, Aquaculture, Volta lake, Lake Huron, Ghana

\section{Introduction}

The oceans cover more than $70 \%$ of the earth and support ultimately all living organisms. More than half of the world's population lives within 50 miles of a coastline, making us inseparable from the oceans, yet, only $5 \%$ of the ocean has been explored (NOAA, 2013; Bauman, 2013). In their daily work Hydrographers explore the waters. IHO (2013) defines Hydrography as:

"The branch of applied sciences which deals with the measurement and description of the physical features of oceans, seas, coastal areas, lakes and rivers, as well as with the prediction of their change over time, for the primary purpose of safety of navigation and in support of all other marine activities, including economic development, security and defence, scientific research, and environmental protection".

Although hydrography was intended mainly to support vessels navigate safely, the increased shift of attention from nautical charts to marine resources after the Second World War especially to the hydrocarbon industry expanded the use of hydrographic data (Ingham and Abbott, 1992). Currently countries with hydrographic capabilities are able to use hydrographic information to support different maritime and related activities (IHO, 2013). In the developed countries, Hydrography and hydrographic data are of immense importance not for mariners alone but for many other users. All activities undertaken in the maritime domain like environmental protection management; control of coastal erosion; extraction of mineral deposits; tourism; establishment of dumping grounds for industrial waste; fishing; renewable energy and aquaculture just to name a few are supported with hydrographic information (Ehlers et al, 2002). Hydrography is a precursor activity to all activities in the marine environment and helps reduce the cost of undertaking such activities.

\section{Literature Survey}

The Fisheries sector is one of the most important sectors that contribute significantly to Ghana's economy. The sector provides employment for many people particularly those living near the country's $550 \mathrm{~km}$ coastline and other water bodies (La Pierre, 2004), it provides food security and brings the country about 60 million dollars of foreign exchange earnings annually. About two million people are believed to be working in different capacities in this sector. About 3.9 percent of the country's gross domestic product (GDP) is contributed by this sector. It is also a contributor of 11 percent of Ghana's agricultural GDP. In Ghana, fish is the number one and preferred choice of animal protein because it is relatively cheap. Only 15 percent of the annual total production of fish is exported the other 75 percent is consumed locally, this is evident in the $25 \mathrm{~kg}$ per annum average per capita fish consumption in Ghana which exceeds the $13 \mathrm{~kg}$ world average. The country has a $50 \%$ short fall in fish requirements which cost the nation $\$ 200$ million worth of fish import (MoFA, 2004; BoG, 2008).

Aquaculture is the farming of aquatic animals and plants and the use of human interventions during the process to increase production (WHO, 1999). Bulk of the country's aquaculture production comes from the Volta Lake (about 90\%) (BoG, 2008), where the farmers practice cage aquaculture (figure 1). 
International Journal of Science and Research (IJSR)

ISSN (Online): 2319-7064

Index Copernicus Value (2013): 6.14 | Impact Factor (2014): 5.611

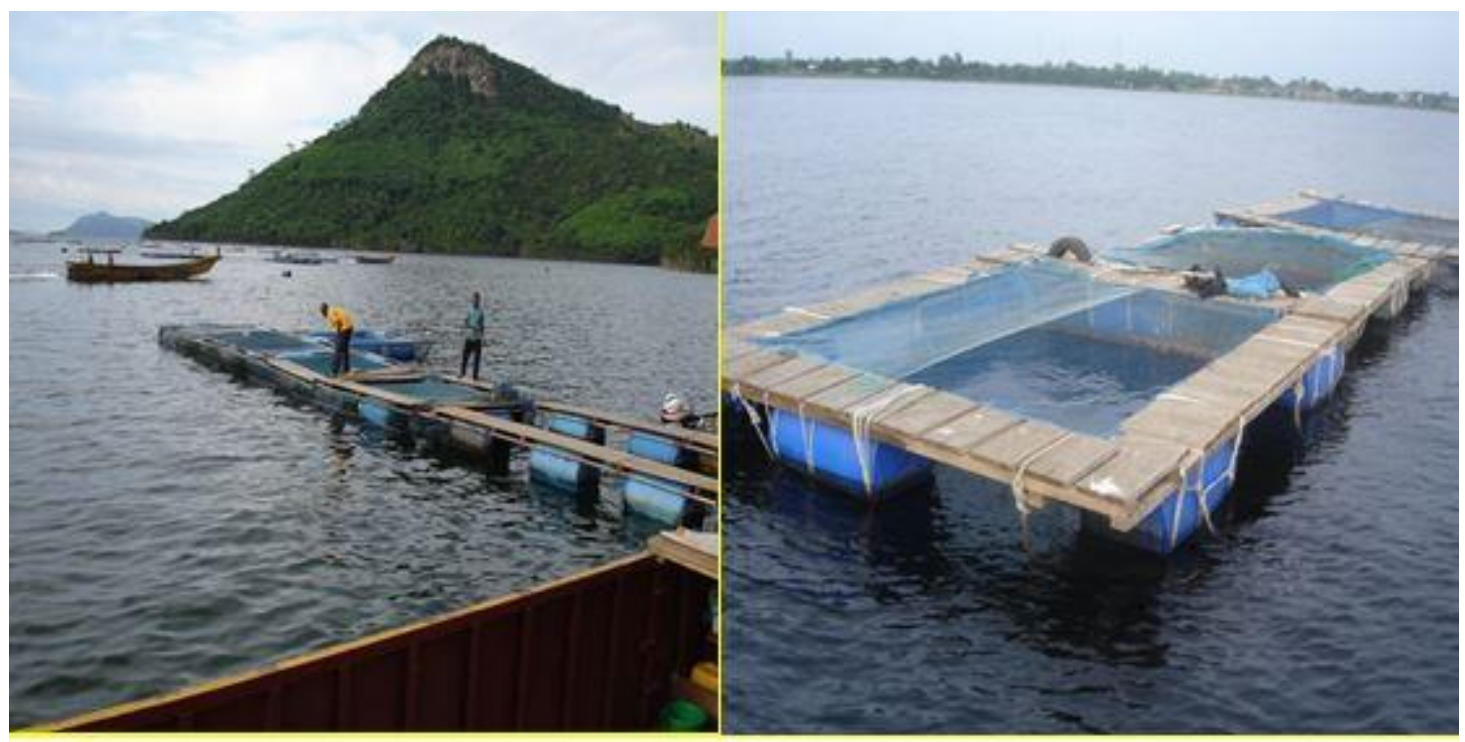

Figure 1: Fish farming in cages on the Volta Lake source: (Sarnissa, 2014)

A total of 950 tonnes of fish were produced from fish farming in 2004 alone, the annual production of fish farming has being estimated to be around of $\$ 1.5$ million dollars. Aquaculture is seen as the best option of bridging the country's short fall in fish requirements (MoFA, 2004; BoG, 2008), but in order for the aquaculture sector to reach its full potential, problems of fish farmers competing for suitable development sites and having access to natural ecosystems need to be addressed (MoFAD, 2011).

\section{Approach}

Data was mainly from secondary means. This was made possible through both library and internet research. An internet research was carried out by sourcing information from experts and professionals that are published online. Information was also gathered from official websites of relevant institutions and entities. Data was collected from books, journals, and annual reports through library research. Consultations were also made with knowledgeable individuals in the hydrographic surveying industry; in situations where this wasn't possible, secondary data were relied on. Current trends on how Canada is using hydrography to supports the sector under consideration were also studied. All these were analysed to achieve the aim of the research

\subsection{Inland Aquaculture on Lake Huron}

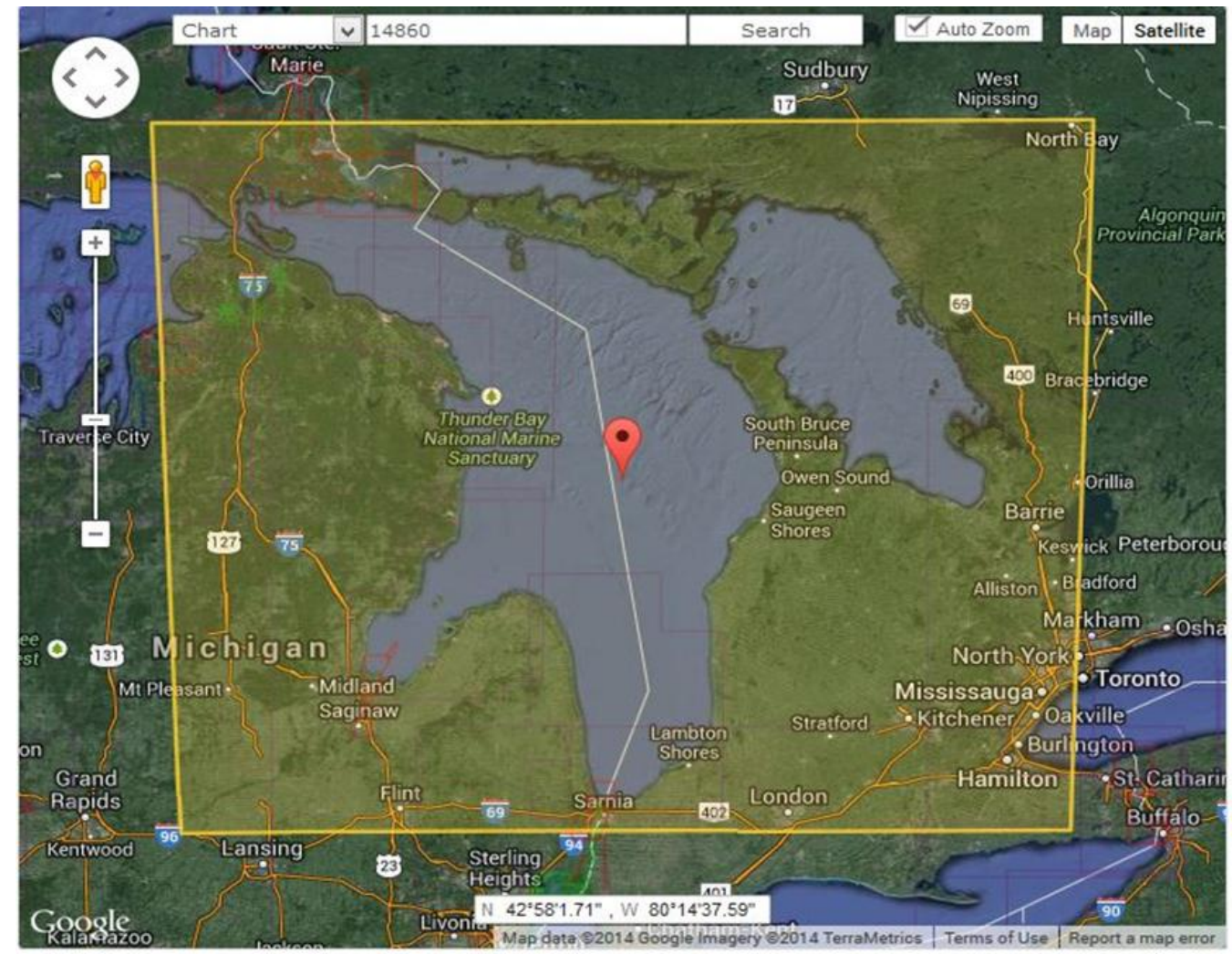

Figure 2: Satellite imagery of Lake Huron Source: (NOAA, 2014)

Volume 5 Issue 2, February 2016

www.ijsr.net 


\section{International Journal of Science and Research (IJSR) \\ ISSN (Online): 2319-7064 \\ Index Copernicus Value (2013): 6.14 | Impact Factor (2014): 5.611}

Lake Huron (figure 2) in terms of volume is considered the fifth largest in the world. It has a length of $332 \mathrm{~km}$ and breadth of $295 \mathrm{~km}$. It has a mean depth of $59 \mathrm{~m}$ and goes as deep as 229m in some areas (Ylvisaker, 2004). Lake Huron together with Lake Superior, Ontario, Erie and Michigan make up the world's largest freshwater network (ecosystem) (Abell et al, 2000). Almost all the cage aquaculture operation on the lake takes place at the North Channel which is about $150 \mathrm{~km}$ long, with a width of about $35 \mathrm{~km}$ and an average depth of $22 \mathrm{~m}$. The surface area of the North channel is about $3950 \mathrm{~km}^{2}$ (Patterson and Blanchfield, 2013).
The survey and charting of Lake Huron was started in 1883 using leadlines and triangulation methods (CHS, 2014). Over the years, the lake has undergone resurveys to update the charts; new survey techniques like multi beam echosounding are now used to provide a more detailed account of the lake's floor to support the charts (FOH, 2001; NOAA, 2009). Depths of the chart of Lake Huron (figure 3) are reduced to International Great Lakes Datum 1985, which is based on low water established by observing water levels for a period (US Army Corps of Engineers, 1992)

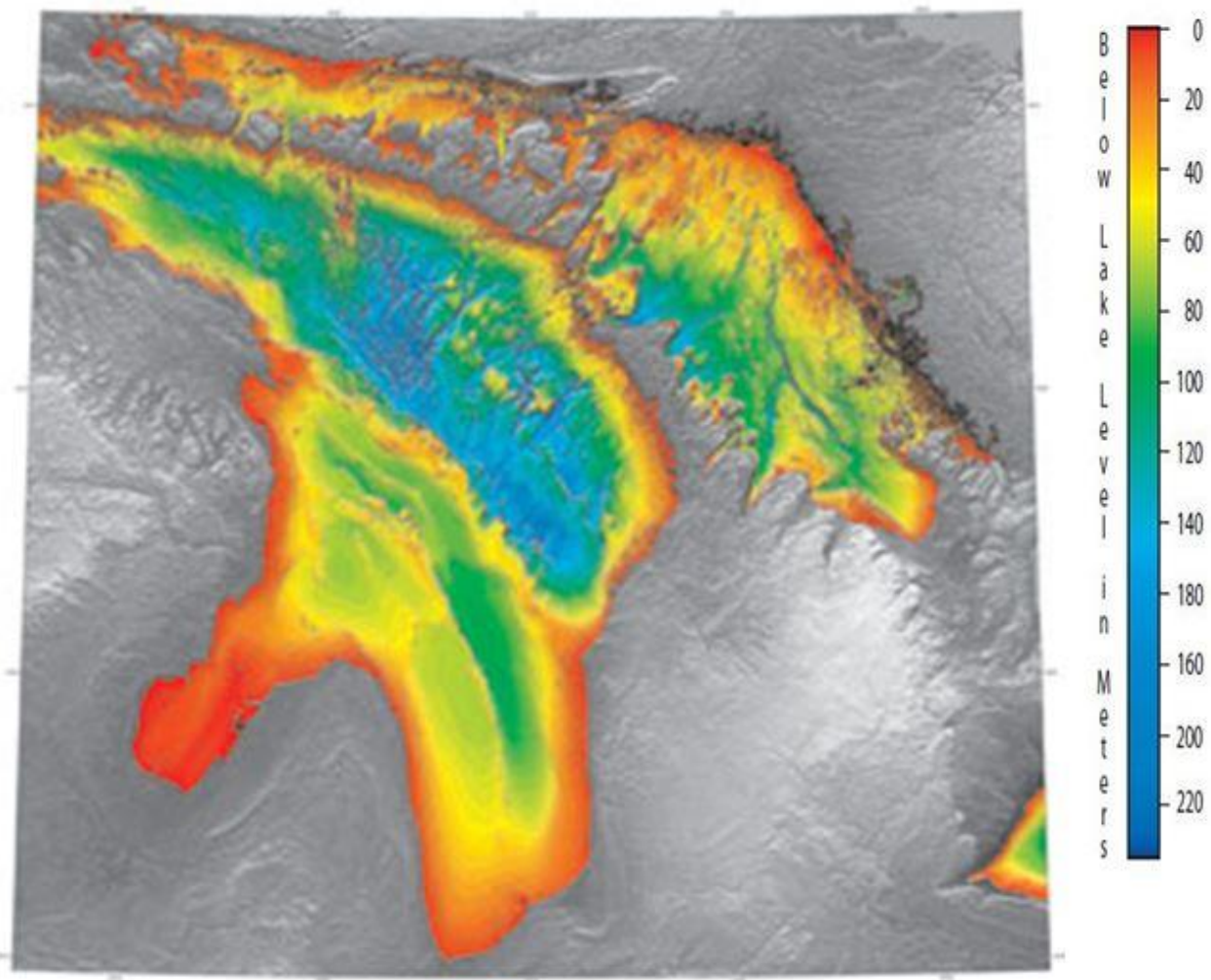

Figure 3: Bathymetric chart of Lake Huron source: (NOAA, 2001)

Chart and bathymetric data produced are readily available to the fishing industry, and are used in the selection of a suitable site for aquaculture fish farming and to determine the solids wastes from the cage farm that accumulate on the lake bed (Cromey et al, 2002; NOAA, 2009; Aquaculture Association of Canada, 2011). These data are also used to plan aquaculture sites efficiently to increase production and to have a sustainable operation (Cannon and Nairn, 2009).

Cage aquaculture operation on Lake Huron has expanded over the years contributing most of Ontario's aquaculture production (Bredin, 2002).

\subsection{Method of producing a bathymetric Chart of Volta Lake}

A bathymetric chart of the portion of the Lake used for aquaculture can be produced from the following steps:

\subsubsection{Establishing Controls}

Surveying the Lake Volta like all surveys whether on land or water will require establishing controls (horizontal and vertical), this will make it possible to ascertain the position of points with the accuracy desired and will aid in the preparation of the chart (Odling-Smee, n.d, Uren and Price, 2010). It is always better to bring in the survey control to the survey area, even though this will involve greater expense, it will be extremely beneficial when the survey has to be extended at a later time (Ingham, and Abbott, 1992).

\subsubsection{Horizontal control}

The local control network which is based on the national control network should be extended to the survey area (Lake Volta), this can be achieved by employing land surveying techniques, mainly traversing, intersection and resection (Ingham and Abbott, 1992). Through these methods positions of stations can be established which will be used to determine positions of other points. The accuracy aimed at will influence the instrument selected and the procedure taken to establish the controls. This should be well documented as errors incurred in establishing the control network will be transferred to the positions of points that will be determined (Ingham, 1975)

\subsubsection{Vertical control}

In Ghana the mean sea level which was observed in a year period and is the local representation of the geoid is used as datum for measuring orthometric heights (Ayer and Fosu, 


\section{International Journal of Science and Research (IJSR) \\ ISSN (Online): 2319-7064 \\ Index Copernicus Value (2013): 6.14 | Impact Factor (2014): 5.611}

2008), but hydrographic surveys with the exception of those carried out for civil engineering projects are based on a different datum, usually low water level datum. Using this datum provides users of a chart the assurance of the minimum water level available at any point in time no matter the heights (Ingham and Abbott, 1992). The International Great Lakes Datum 1985, the datum used to reduced depths on chart of Lake Huron, is based on low water (US Army Corps of Engineers, 1992).

Low water level of the Volta Lake can be obtained by deploying a Valeport VRS-20 Tide Gauge (provides an accuracy of $\pm 10 \mathrm{~mm}$ ) at strategic point and observing the water levels for a period. Observing for a longer duration improves the result but will involve greater expense in maintaining the water level gauge. Data from the gauge will then be used to determine the low water level datum. After the datum is determined, this will be used as a reference point to establish vertical controls (benchmarks) around the survey area (Ingham and Abbott, 1992: Uren and Price, 2010).

\subsubsection{Survey}

A small vessel should be used for this work, with a laptop installed with navigation software to help in planning of the survey lines and navigation. Survey lines should be run perpendicular to the bathymetric contour (Ingham and Abbott, 1992), with spacing of $10 \mathrm{~m}$ to produce a chart of scale 1:1000. Marimatech E Sea Sound 206 single beam echosounder, which is ideal for both offshore and nearshore surveys will be used for this task. At a frequency of 200 $\mathrm{kHz}$, the E Sea sound 206 provides $1 \mathrm{~cm}$ accuracy, which is $\pm 0.1 \%$ of depth value when the sound velocity is corrected. Trimble Real Time Kinematic (RTK) GPS will be set on one of the established horizontal control to provide differential corrections to the rover GPS on the vessel (provides $\mathrm{cm}$ accuracy). GPS provides coordinates on the WGS 84 ellipsoid; these coordinates can be transformed to either the War Office or Clark 1880 ellipsoids using readily available transformation parameters. Prior to every survey a bar will be lowered beneath the transducer at different depths (say two metre intervals) and the echosounder used to record the right depth by adjusting the sound velocity (IHO, 2005). Valeport VRS-20 Tide Gauge deployed at a strategic place will provide the water level data that will be used to reduce the soundings. The data from the surveys will then be processed; a chart will then be produced using ArcGIS (Barton 2011; Roger, 2012)

\subsection{Method of determining the water quality and water current}

A Valeport 106 current meter should be used to take samples at different locations on the Lake. The current meter will be attached to a cable and lowered at $2 \mathrm{~m}$ interval from the surface to a desired depth. Vector averaging of the current meter is based on measuring impeller counts and one compass reading in a period of one second. The vector averages are developed over an averaging period. Optional parameters will be obtained by averaging the sample that will be taken over each sample period. Display of real time will be updated together with the memory after every averaging period. Table 1 shows the accuracy, range and resolution of the sensors of the Valeport. At each sampling location, the temperature, speed, salinity, density, depths and direction of the water column will be recorded at 2 metre depth increment and the data processed (Valeport, 2011). Other sensors will be fixed to the transducer of the single beam echosounder to measure the $\mathrm{pH}$, turbidity and dissolved oxygen (Barton, 2011).

Table 1: Accuracy, range and resolution of Valeport sensors

\begin{tabular}{|c|c|c|c|}
\hline Sensor & Accuracy & Range & Resolution \\
\hline Speed & $\begin{array}{c} \pm 1.5 \% \text { of reading } \\
\text { above } 0.15 \mathrm{~m} / \mathrm{s} \\
\pm 0.004 \mathrm{~m} / \mathrm{s} \text { below } \\
0.15 \mathrm{~m} / \mathrm{s}\end{array}$ & 0.03 to $5.0 \mathrm{~m} / \mathrm{s}$ & $0.001 \mathrm{~m} / \mathrm{s}$ \\
\hline Direction & $0.25^{\circ}$ & $0-360^{\circ}$ & $0.25^{\circ}$ \\
\hline Temperature & $0.02^{\circ} \mathrm{C}$ & -5 to $35^{\circ} \mathrm{C}$ & $0.01^{\circ} \mathrm{C}$ \\
\hline Pressure & $\pm 0.2 \%$ Range & $\begin{array}{c}50,100,200 \text { or } \\
500 \mathrm{dBar}\end{array}$ & $0.025 \%$ Range \\
\hline
\end{tabular}

Source: (Valeport, 2011)

\section{Discussion}

In fish farming, selecting a suitable site goes a long way in determining how successful the farm will be. Hence, in order to reduce operational cost and mortality and increase fish production, the selection of a suitable site is of great importance (Beveridge, 2004). Site selection in fresh water cage fish farming depends on three main factors namely: water quality, water depth and water current (FAO, 2002).The water quality of sites for cage fish farming should be good to support the growth of the fishes. For the water to be deemed to be of good quality, certain physical requirements needed for the species survival have to be met. These physical factors include temperature of the water, its $\mathrm{pH}$, turbidity and dissolved oxygen (FAO, 2002; Beveridge, 2004). The sensors on the Valeport together with that attached to the echosounder will provide figures that can be compared to the standards needed for the species that are going to be farmed. In this case, the temperature, salinity, $\mathrm{pH}$, turbidity and the dissolved oxygen measured will be used in making an informed decision in choosing the right site. Water current improves the dissolved oxygen and takes out the toxic metabolic waste from locality of the fish (Beveridge, 1984). The ideal current for a site selection should be $10-30 \mathrm{~cm} / \mathrm{s}$ based on the nutrients content of the water (Pillay, 1990). Extremely high currents lead to a loss of food and have a negative impact on the behaviour of the fishes (Beveridge, 2004). Results of the water current from the Valeport current meter taken at different locations on the portion of the lake that is being charted will also be used to determine the area with the right water current to take away the metabolic waste from the locality of the fish. The water current will also aid in making an informed decision of the right nutrients content of the water. Cages used for fish farming should be positioned at a suitable depths off the bottom of the water. Positioning the cage at an appropriate depth enhances the exchange of water and keeps the cage clear off the habitat of the benthic community. Also having the cage at an appropriate depth and not too close to the substrate ensures drawing of water from the sides and the bottom as well. The most suitable depth to hold fishes is at 4 - $5 \mathrm{~m}$ above the bottom of the water (Beveridge, 2004). The chart produced will help in planning where to site the cages.

\section{Volume 5 Issue 2, February 2016}




\section{International Journal of Science and Research (IJSR) \\ ISSN (Online): 2319-7064 \\ Index Copernicus Value (2013): 6.14 | Impact Factor (2014): 5.611}

From the depths on the chart and the water level information, the cages can be placed at positions where they will be 4-5m off the bottom of the water at any point in time, to enhance the exchange of water and keep the cages clear off the habitat of the benthic community (Beveridge, 2004: Pillay, 1990). The bathymetric data can also be used to determine and manage the solid waste accumulation on the lake bed (Cromey et al, 2002).

\section{Conclusion}

Thus, integrating hydrography into inland aquaculture on the Volta Lake will help to develop more suitable sites and also help to locate natural ecosystems for the fishes, leading to the reduction of mortality and an increase in fish production

\section{References}

[1] Abell et al., 2000. Freshwater ecoregions of North America: a conservation assessment. Washington DC: Island Press

[2] Aquaculture Association of Canada, 2011.Aquaculture R\& D Review 2011. Canada: Dollco

[3] Ayer, J and Fosu, C., 2008. Map Coordinate Referencing And The Use Of GPS Datasets In Ghana. 116 Journal of Science and Technology, Vol. 28, No. 1, April 2008

[4] Barton, A., 2011. Investigating the Role of Hydrography in the Establishment of an Inland, Cage Aquaculture Development .MSc. Plymouth University

[5] Bauman, J., 2003. GIS in the Zone. [online] Available at international.com/issues/articles/id65-

GIS_in_the_Zone.html [Accessed 5 February 2014]

[6] Beveridge, M. C. M., 1984. Cage and Pen fish farming. Carrying capacity models and environmental impact. F.A.O Fish. Tech. pap., (255): 131 p.

[7] Beveridge, M. C. M., 2004. Cage Aquaculture. 3rd ed.UK: Blackwell Publishing Ltd

[8] BoG. 2008. The Fishing Sub-sector and Ghana's Economy. Accra: Research Department Bank of Ghana

[9] Bredin, J., 2002. Lake Huron Initiative Action Plan Update. Michigan: Department of Environmental Quality

[10]CHS, 2014.Our History. [online] Available at http://www.charts.gc.ca/about-apropos/histo-eng.asp [Accessed 16 July 2014]

[11] Cannon, B. D. and Nairn, R., 2009. Economic Impacts of Hydrographic Surveys. [online] Available at http://www.fig.net/pub/figpub/pub57/pub57_full.pdf [Accessed 17 July 2014]

[12] Cromey, C. J., Nickell, T. D. and Black, K. D., 2002. DEPOMOD - modelling the deposition and biological effects of waste solids from marine cage farms. Elsevier Aquaculture 214 (2002) 211 -239

[13] Ehlers et al., eds., 2002. Marine issues: From a Scientific, Political and Legal perspective. The Netherlands: Kluwer law international

[14]FAO, 2002.Inland Aquaculture Engineering. [online] Available http://www.fao.org/docrep/x5744e/x5744e0f.htm [Accessed 11 July 2014]
[15] Friends of Hydrography, 2001.History of CHS. [online] Available http://www.canfoh.org/Intro\&Hist/history_of_chs1.htm [Accessed 16 July 2014]

[16]IHO, 2005. Manual of Hydrography.1st ed. Monaco: IHO

[17]IHO, 2013.Definition of Hydrography. [Online] Available at http://www.iho.int/srv1/index.php?option=com_content \&view=article\&id=299\&Itemid=289 [Accessed 13 June 2014]

[18]IHO, 2013. Status Report On Hydrography And Mapping Of The World's Seas, Oceans And Coastal Waters.[online] Available at https://ggim.un.org/docs/meetings/3rd\%20UNCE/EC.20-2013-

10_IHO\%20Land\%20and\%20Marine\%20background\% 20paper.pdf [Accessed 22 June 2014]

[19] Ingham, A. E., 1975. Sea Surveying.vol. one. Great Britain: John Wiley

[20] Ingham, A. E and Abbott, V. J., 1992.Hydrography for the Surveyor and Engineer. London. Blackwell Publications.

[21] La Pierre, Y., 2004. Ghana in Pictures. USA: Lerner Publication Company

[22] MoFA, 2004.Information of Fisheries in Ghana. Accra: Ministry of Food and Agriculture

[23] MoFAD, 2011.Fisheries and Aquaculture Sector Development Plan.Accra: Ministry of Fisheries and Aquaculture Development

[24] NOAA, 2001. Bathymetry of Lake Huron. [image online] Available at http://www.ngdc.noaa.gov/mgg/greatlakes/huron.html [Accessed 16 July 2014]

[25] NOAA, 2009.Great Lakes Bathymetry. [online] Available

http://www.ngdc.noaa.gov/mgg/greatlakes/greatlakes.ht $\mathrm{ml}$ [Accessed 16 July 2014]

[26] NOAA, 2014.Satellite imagery of Lake Huron. [image online] Available at http://www.charts.noaa.gov/InteractiveCatalog/nrnc.sht ml?rnc=14860 [Accessed 16 July 2014]

[27] Odling-Smee, P. G., nd. Some notes for guidance of students in hydrographic surveying. vol one. UK: Plymouth University

[28] Pattersn, K. and Blanchfield, P. J., 2013.Oncorhynchusmykiss escaped from commercial freshwater aquaculture pens in Lake Huron, Canada. Aquacult Environ Interact 4: 53-65, 2013

[29] Pillay, T. V. R., 1990. Aquaculture Principles and Practices. UK: Blackwell Science ltd

[30] Roger, A., 2012. Hydrographic Report: Fish farm site Gighay, Barra, Western Isles. Report no. NAL-hydro13_12

[31] Sarnissa, 2014.FAO Ghana Aquaculture overview. [image online] Available at http://www.sarnissa.org/Ghana [Accessed 16 June 2014]

[32] Uren, J. and Price, B., 2010.Surveying for Engineers. 5th ed. UK: Palgrave Macmillan

[33] US Army Corps of Engineers, 1992. [online] Available at 


\section{International Journal of Science and Research (IJSR) \\ ISSN (Online): 2319-7064}

Index Copernicus Value (2013): 6.14 | Impact Factor (2014): 5.611

http://www.in.gov/dnr/water/files/11WhatIsIGLD1985.

pdf [Accessed 20 June 2014]

[34] Valeport, 2011. VALEPORT Model 106 Current Meter.

[online] Available

at

http://www.valeport.co.uk/Portals/0/Docs/Datasheets/V aleport_Model106_v2a.pdf [Accessed 18 July 2014]

[35]WHO, 1999. Food Safety Issues Associated With

Products From Aquaculture: report of a joint FAO/NACA/WHO study group. Geneva: WHO

[36] Ylvisaker, A., 2004. Lake Huron. USA: Capstone Press 